\title{
Building a CPTED research culture in Portugal: a bibliometric and social network analysis
}

\author{
Miguel Saraiva $^{1} \cdot$ Ana Amante $^{1} \cdot$ Hélder Santos $^{1} \cdot$ Paula Ribeiro $^{1}$
}

Published online: 29 February 2020

(c) The Author(s) 2020, corrected publication 2020

\begin{abstract}
Although CPTED is recognized as an important crime deterrent for some decades, there are countries where it is still in its infancy, and knowledge and dissemination are scarce. Portugal is such an example. Only in the last decade has research specifically focused on CPTED, with little convergence between the different spheres of knowledge production, such as the academia, the police or the administration. In this paper, we argue that to build a CPTED culture, these spheres need to converge. Using the Portuguese CPTED experience as a case study, we apply methodologies of social network analysis to explore the relationships between different actors and the research time-line. Through a bibliographical analysis, we further delve on the authors and theories that most influenced Portuguese CPTED. This dual approach allows introducing the little known Portuguese CPTED experience to the international community, as well as discussing how the mechanisms of knowledge production integrate towards a more cohesive implementation.
\end{abstract}

Keywords CPTED · Safety · Bibliometric analysis · Social network analysis · Portugal

Miguel Saraiva

miguelmsaraiva@gmail.com

Ana Amante

anatavaresponte@gmail.com

Hélder Santos

hfcs75@hotmail.com

Paula Ribeiro

paularibeiro82@gmail.com

1 CEGOT - Centre of Studies in Geography and Spatial Planning, of the Faculty of Arts and Humanities of the University of Porto, Via Panorâmica s/n 4150 - 564, Porto, Portugal 


\section{Introduction and aim}

According to Armitage (2018, p. 1) Crime Prevention Through Environmental Design (known by its acronym CPTED) "represents a multi-faceted approach to crime reduction that draws upon theories from urban design, psychology and criminology". In the words of the EU Council, CPTED is "based on the theory that proper design and effective use of the built environment can lead to a reduction in crime and the fear of crime, as well as an improvement in the quality of life". Thus, it "aims to reduce or even remove the opportunity for crime to occur in an environment and promote positive interaction with the space by legitimate users" (CEU 2011, p. 2).

CPTED has been acknowledged and researched worldwide since the 1970s, through the pioneering works of authors such as Jacobs (1961), Jeffery (1971), Newman (1972, 1996), Brantingham and Brantingham (1981), Crowe (1991) or Clarke (1992). Nonetheless it seems now to be living its greatest period of acceptance and application in Europe [see reviews such as Soomeren (1987, 2014), Cozens et al. (2005), Cozens and Love (2015), Hollis-Peel et al. (2011), Michael et al. (2012), Gibson and Johnson (2013), Johnson et al. (2014), Grönlund (2014), Armitage (2016) or Haider and Iamtrakul (2018)]. Although the number of crimes recorded in the EU-28 has been steadily decreasing since 2003, types of crime such as domestic burglary or sexual offense have had increases in particular countries (Eurostat 2016). This, along with contextual factors stemming from the economic crisis, social tensions and the terrorist threat (Vieno et al. 2013), as well as an increased awareness derived from scientific research and professional and practitioner's associations, have consistently added CPTED to discourses on European Safety in the last two decades.

In 1996, the International CPTED Association (ICA) was founded, followed in 1999 by the UK-based Design Out Crime Association (DOCA), which expanded to the rest of Europe in 2001 to become known as EDOCA. On that same year, the European Council established an European Crime Prevention Network (EUCPN) whose reports describe CPTED as "a useful, effective, very concrete and feasible strategy" (EUCPN 2002, p. 48) and a "pro-active crime prevention philosophy" (CEU 2011), whose best practices "should be collected, evaluated and made accessible for stakeholders" (EUCPN 2002, p. 48). Also in 1996, work started on the preparation of an European Standard, finally published in 2007 as Standard TR14383-2 Crime Prevention-Urban Planning and Design. Along with an associated Handbook (see Cardia 2013) this Standard further diffused CPTED strategies to researchers, professionals and local authorities. COST Action TU1203: Crime Prevention Through Urban Design And Planning, which occurred between 2012 and 2016 and included 26 participant European countries, further disseminated the Standard, structured existing knowledge in the EU and helped develop innovative approaches.

Nonetheless, acceptance of CPTED into each country's planning and design practices has not been similar throughout Europe, as Oxley (2005), Stummvoll (2012) and Grönlund (2014) demonstrate. Countries such as the UK, the 
Netherlands or Denmark have a CPTED culture dating from the 1980s, and others as France and Germany have it since at least the 1990s. On the other hand, southern and eastern European countries have only gradually introduced CPTED in the twenty-first century and only a few have adopted major manuals and standards such as the European Standard (Stummvoll 2012; Grönlund et al. 2014; Oxley 2005). Several authors have tried to explain the reasons for this (Schubert et al. 2016; Chiodi 2016; Saraiva et al. 2016; Armitage 2018; Gibson and Johnson 2013; Ekblom 2011b; Davey and Wootton 2017). Such reasons include unawareness derived from the absence of a proper scientific research background in some countries, and ambiguity in crime prevention terminology between experts, countries, and relevant documents. Furthermore, some national and local authorities demonstrate reluctance to change from traditional crime deterrents, perceptions of panacea and an absence of top-down directives to support implementation. As Davey and Wootton (2017) discuss, the idea of a standard norm does not appear to fit comfortably with police forces and city authorities committed to respond to local needs.

Portugal, at the western edge of Europe, is one of these countries where a particular emphasis on CPTED has only happened in the last decade. Section 2 discusses three main reasons for this; the publication of the European Standard on Crime Prevention in 2007, the subsequent increase in awareness in research and practice, and the increase in crime and insecurity in Portugal, also associated to a period of economic crisis. Moreover, although Portugal is listed in the paper by Cozens and Love (2015) as one of the countries where the government supports CPTED, it is actually not a legal requirement. This has resulted in a very little known use of CPTED in urban projects and being practically absent in administration guidelines and academic training. Major institutional and research documents supporting CPTED have only been published after 2010, with top-down directives including a CPTED bestpractice manual in 2013 and a non-mandatory recommendation made in the 2015 National Strategy for Housing (Saraiva et al. 2016). Although some of these documents are listed in the EDOCA website, they are only known to small group of professionals and researchers in Portugal, and to even less members of the international crime-prevention community. Knowledge is still recognizably dispersed and furthermore, as this paper will demonstrate, there is little integration between the different spheres of production and implementation (as the academia, police or the administration) and little integration between the various areas of expertize (as architecture, planning or law).

Today, the portuguese Ministry of Internal Administration is promoting a new generation of Local Safety Contracts with municipalities (MAI 2016), which have picked up on the recent debates on CPTED-based strategies. This increased awareness led to the appearance of a small number of documents that tried to summarize and disseminate the evolution of CPTED research and practice in Portugal (Saraiva et al. 2016, Rodrigues 2016; Baptista 2015; Diniz et al. 2016). However, these listings are manifestly incomplete, as they consider less than half of the Portuguese works which acknowledge CPTED. There has not been a scientific paper exclusively concerned with presenting the Portuguese CPTED history and literature to the international community. In fact, there is very little international literature analyzing the time-line of CPTED research in 
smaller countries, for example those outside central Europe, where there are no proper legal frameworks for its implementation. Review papers as the above cited and others as Jongejan and Woldendorp (2013), Monchuk and Clancey (2013) or Monchuk (2019) generally focus on the major advances related to theory, policy and practice in countries as the UK, US, Australia, Netherlands or Denmark. Few reports, such as that of EU-project COPS (Oxley 2005) or of COST Action TU1203 (Grönlund 2014) consider other European countries, albeit through general overviews. On the other hand, more detailed papers on countries such as Japan (Hino and Schneider 2013), Portugal (Saraiva and Pinho 2011), Lithuania (Saraiva et al. 2016), Malaysia (Shamsuddin and Hussin 2013), Botswana (Cozens and Melenhorst 2014) or United Arab Emirates (Ekblom et al. 2013) dwell on specific pilot studies, best practices or methodological processes.

Actually, few scientific works have raised self-awareness by exploring not just how processes and policies have evolved in a given country, but how authors and their researches have played an important part in national discourses. In this paper we accomplish that by analyzing research time-lines, how authors have worked together and which theoretical currents and bibliographical sources have influenced their publications. Consequently, we have applied bibliometric and social network analysis (SNA) techniques (Borgatti et al. 2013; Spinak 1996) to identify the mechanisms of knowledge production. Such techniques have previously been used in crime-related research, for example, to describe cloud forensics research trends (Baldwin et al. 2018), human trafficking research trends (Sweileh 2018) or the author communities associated to the Evolution of the Environmental Criminology and Crime Analysis (ECCA) Symposiums (Bichler and Malm 2008). However, as far as we are aware, this is their first use in the analysis of CPTED research and time-lines.

Therefore, this paper has a dual goal. First, to introduce to the international community the little known Portuguese CPTED, by tracing its evolution in terms of major authors and publications, and the waves of thought that have influenced them. Second, to introduce known research methodologies of social and information sciences to CPTED research. The creation of networks of authors and citations serves as a means for conceiving an evaluation and awareness-raising tool of knowledge transfer, integration and implementation. This is all the more important in countries with poor CPTED tradition, where knowledge structures are still not properly defined, understood or even known by the actors themselves.

This paper is organized thus: the second section introduces in more detail the Portuguese case study; the third section discusses the paper's methodology; the fourth and fifth summarize the evolution of CPTED research in Portugal, including the existing knowledge network of authors; the sixth displays the analysis of cited publications; and in the seventh, discussion and conclusions are drawn.

\section{Case study presentation}

Portugal is a small western European country with about 10 million inhabitants and 89 thousand square kilometers of area (INE 2019). It possesses 308 municipalities; 278 in the mainland, and a further 30 in the islands of Madeira and Azores. The 
planning system is ruled by the Portuguese Basic Law on Spatial Planning Policy and Urbanism initially approved in 1998 (updated in 2014; Law no 31/2014), which encompasses a National Program for Territorial Planning Policies (PNPOT; revised in 2019; Law n ${ }^{\circ}$ 99/2019), and lower-level regional (PROT), and municipal (PMOT) plans (which will be revised in the upcoming years). These revisions promote the territorial dimension of public policies at various scales, through the support of a territorial organization oriented towards cohesion, an integrated and competitive economy (particularly outside major cities), and the improvement of quality of life. This is particularly pressing as Portugal is moving past an economic crisis period in the early 2010s, which lead to increased unemployment, public debt and a string of austerity policies (Bosco and Verney 2012; Torres 2009; Carneiro et al. 2014).

Nonetheless, Portugal is considered one of the safest countries in the world. It is in third place in the Global Peace Index (IEP 2019) and has one of the lowest victimization rates in Europe (Grangeia et al. 2013). For example, in 2016 it was the fifth country in Europe with the lowest murder rate (Eurostat 2016). In the last decade, overall criminality has decreased in $21 \%$, whereas violent crimes have decreased in 43\% (SSI 2019). Notwithstanding, recent reports shown an increase of specific types of crime in the last couple of years, such as assault, domestic and sexual violence or elderly abuse (APAV 2017; PORDATA 2019). Furthermore, Portugal is also one of the countries in Europe where the population is more preoccupied with crime (Tulumello 2018) and that has more police officers per 100.000 inhabitants (Eurostat 2016).

Law no 5/1999 moved the Portuguese Public Safety Police from a military to a more civil model. In the words of Tulumello (2018) security was democratized, with the creation of the basis for proximity and community programs in the twenty-first century. The Law of Internal Security ( $n^{\circ}$ 53/2008) maintained a state-responsibility for security, through the Ministry of Internal Administration; however, the subsequent National Strategy for Security allowed for a more reactive capacity in security forces and the training of agents for preventive and proximity paradigms (Silva 2013c). In Portugal, the main organizations of police, as described by Durão (2011), are the Public Safety Police, with jurisdiction in the main urban areas, the National Republican Guard, in smaller cities and rural outposts (both under the tutelage of the Internal Administration) and the Judiciary Police, for forensics and research, under the tutelage of the Ministry of Justice.

Concern of these entities over local safety policies in Portugal has been particularly evident since 2007, due to two main reasons. The first is the publication of the European Standard on Crime Prevention and other documents, which contributed to the European debate and an increase in awareness. The second was the somewhat unexpected, but well documented, increase of crime in Portugal which occurred between 2007 and 2009, a consequence, among other reasons, of the economic crisis (Machado and Santos 2009; Tulumello 2014; PORDATA 2019). Along with notorious media-covered crimes in the summer of 2008, the Portuguese Observatory for Safety, Organized Crime and Terrorism registered in that year unprecedented levels of fear of crime (Tulumello 2018).

Since 2016, with the process of administrative decentralization, the Internal Administration has promoted a greater articulation with local powers. The Local 
Safety Contracts, initially created in 2008, started a second generation in 2016, with municipalities having an increased role in performing safety diagnosis and implementing solutions. This is also related to the new Integrated Proximity Policing Model, that has over 1.000 agents in its ranks, and to a greater knowledge and awareness of environmental criminology principles. Even so, it is noteworthy that the Portuguese branch of the European Forum for Urban Security was only composed of twelve Portuguese municipalities.

In this framework, CPTED is still very much out of the equation. The Crime Policy Law of 2009 does not refer to CPTED, only to "programs of community safety and plans of proximity policing". The main laws concerning urban planning, territorial management and construction hardly mention, or not at all, environmental safety principles. Exceptions have been the workshops held at the Lisbon Municipal Police $(2011,2013,2016)$, the publication of a best-practice manual by the Internal Administration in 2013 (DGAI 2013) and the non-mandatory, one-off inclusion of CPTED in the Portuguese National Strategy for Housing (IHRU 2015). As Neves (2012) declared, CPTED "has never been implemented systematically or as part of any strategy in Portugal", a comment reiterated in her forthcoming doctoral thesis. There has not been, so far, a direct transferability of CPTED know-how and processes from administrative and academic documents to the architectural, engineering or planning practices. This may certainly be one of the reasons for the existing dispersion of knowledge and lack of integration between the different spheres of production and implementation.

\section{Methodology}

A database of all applied and fundamental research documents published in Portugal regarding CPTED was created. Regardless of date of publishing, documents were selected as long as they mentioned at least once the acronym CPTED or its Portuguese translation, and their geographical focus was Portugal. They were collected based on the professional knowledge of the authors of this paper, as well as on an extensive literature review. Such review contemplated peer review papers (in both national and international journals), presentations in scientific meetings, advanced academic works (master, post-graduation and doctoral thesis), reports from public and private entities, and other publications. Document search was performed on relevant scientific databases using research keywords on Portuguese and English as "CPTED”, “crime prevention", "defensible space", "(in)security", "urban planning", "urban design" or "Portugal". The documents found are both in the Portuguese and the English languages (as some authors published their works internationally) and are both by Portuguese and international authors (either co-authors or working in Portugal).

Documents found range from 1997 to 2018. The database of authors, co-authors, institutions and bibliographies, corresponding to each of the documents found, allowed the creation of a theoretical time-line of research as well as bibliometric analysis. Such analysis help describe databases using mathematical and statistical methods, thus allowing to uncover the main research themes and keywords, 
the authors and documents most cited, or the underlying theories (Spinak 1996). Software SPSS was used for statistical analysis. Word-clouds of keywords and title words were produced using open-software wordart.com, considering groupings of words whenever logic (such as considering "crime prevention" as a single entry instead of two separate words). Most titles and keywords are originally in Portuguese but were translated to English in order to produce the cloud images for this paper. The Portuguese word "segurança" means both "safety" and "security", so both translations were considered.

Relational databases were produced with NodeXL software, using SNA methodologies (Borgatti et al. 2013). SNA is based on the hypothesis that the attributes of authors (the nodes of the network) are not the only relevant variable in establishing their performance. The connections they establish between them and their relative position is also paramount, as what happens to a given group is, in part, a consequence of the structure of linkages that is created when all the members are considered together. This allowed for a clearer understanding of how CPTED research evolved in Portugal, and how it has been influenced by national and international sources. The constructed author network is a sociocentric, unimodal and undirectional network where the vertexes represent each author and the linkages between them represent the co-authorship connections. The vertexes were classified according to the institutional sphere of each author (the academia, the administration, the police or private companies) and their respective location (in Portugal or abroad). Only one of the documents reviewed was not included in the author network analysis, namely the Portuguese National Strategy for Housing (IHRU 2015), because it did not list specific authors by name, only an institutional authorship.

\section{CPTED research in Portugal: overview}

As far as this paper's authors could ascertain, 54 documents mentioning the acronym CPTED have been produced by Portuguese authors or institutions. These documents were written by a total of 78 authors. Overall, the universities are responsible for almost $60 \%$ of the production, with the Universities of Porto, Coimbra and the NOVA University of Lisbon leading with 5 documents each. Police organizations are responsible for $28 \%$ of production, with the Higher Institute of Police Sciences and Homeland Security ( 6 documents) and the Military Academy (5 documents) as the most productive institutions. Finally, the Public Administration is responsible for the remaining $13 \%$ of documents, with the General Directorate of the Internal Administration producing 4.

Master thesis, both from the academia and the police schools, are the most common type of document, corresponding to $31 \%$ of the production, followed by applied dissertations (13\%), and research reports (11\%). International journal articles correspond to $9 \%$; national articles and manuals to $7 \%$ each; and book chapters, $\mathrm{PhD}$ thesis and conference papers to $6 \%$ each. Books and working papers correspond to $2 \%$ each.

As can be seen in Fig. 1, "CPTED", either in its abbreviated or expanded form, is the most common keyword used, appearing in 13 of the 36 documents containing 


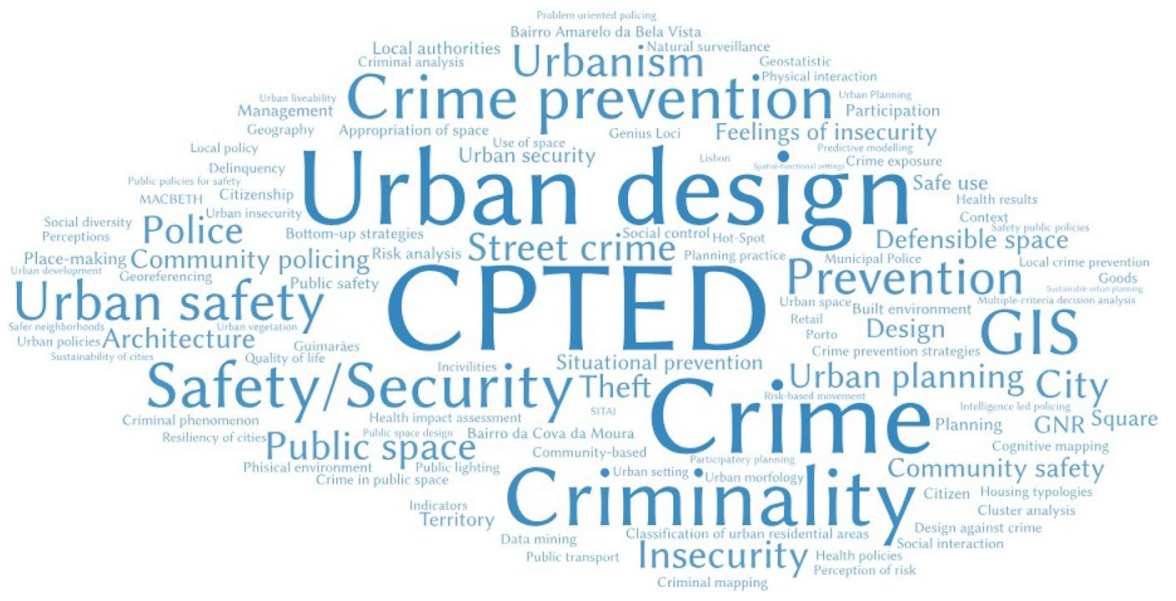

Fig. 1 Keywords cloud (Source: authors; using wordart.com)

keywords. Both "Crime" and "Urban design" appear in 10 of documents, "Criminality" in 7, whereas "Crime prevention", "GIS", "Safety/Security" and "Urban Safety" appear in about 6 each. Other words stand out to a lesser extent such as "Prevention", "Insecurity", "Police", "Urbanism", "City" or "Public space". This shows an association of crime prevention with the disciplines of planning and urban and spatial design. Precisely, "Crime" and "Urban" are the words that most appear on the titles of the documents (Fig. 2). "Crime" appears in over half, mostly within the expression "Crime prevention" (17 times). "Urban" appears in over $40 \%$ of titles, within expressions as "Urban safety" (4 times) and "Urban planning", "Urban design" or "Urban area" (3 times each). The Portuguese word "segurança" (meaning

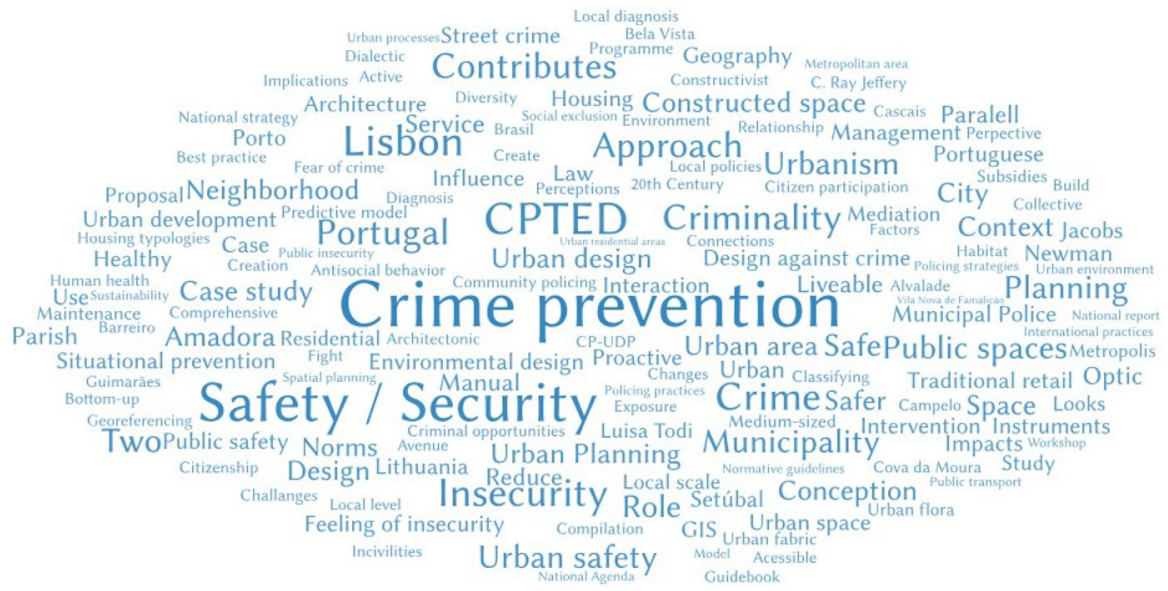

Fig. 2 Title words cloud (Source: authors, using wordart.com) 
either safety or security) is present in 18 titles. "CPTED" appears 8 times and "Insecurity" 6 times. "Lisbon" is the most cited Portuguese city, appearing on the title of 7 documents.

As previously stated, research has mostly occurred from 2007 onwards (Fig. 3). However, production has been somewhat erratic, alternating years of larger production $(2007,2011,2013,2016)$ and smaller production. The year 2011 was the one with the most published documents (8), including the first manual by the General Directorate of the Internal Administration.

\section{CPTED research in Portugal: literature review and knowledge networks}

Table 1 summarizes the papers reviewed in chronological order, making a distinction between the major milestones of CPTED research, awareness and implementation in Portugal, and other research documents. A division can be made between two phases of research, before and after 2013; the date of publishing of the CPTED Best-practice Guidebook by the General Directorate of the Internal Administration (DGAI 2013). The next sections summarize each of these phases, in terms of publications and main findings.

\section{Before 2013}

Until the end of 2012, 28 documents were published in Portugal mentioning CPTED, which were written by a small community of 36 authors. Figure 4 displays the author network using a measure of local centrality. This measures in each node the amount of co-authorship connections a given author possesses. Over half of the authors were not connected between themselves, and it is also noticeable that the spheres of learning (administration, academia and the police) had no interaction.

The earlier works from the academia (Fernandes 1997; Sampaio 2007; Cruz 2005) do not specifically focus on CPTED, rather briefly discuss the theoretical origins and principles of the discipline within more comprehensive studies on safety in urban and transport planning. Nonetheless, Cruz (2005) describes CPTED as a key strategy and Sampaio (2007) calls attention to the lack of awareness within municipalities, who mainly look at urban safety as a competence for the police. This year of 2007 saw a breakthrough in CPTED research. A paper by Heitor (2007) on natural surveillance presents CPTED as a strategy for diminishing feelings of insecurity, whereas the book "Urbanism, Safety and Law" (Valente 2007) includes chapters by Fernandes (2007) and Gomes (2007), former director of the Public Security Police, which constitute the first overall reviews of CPTED principles in portuguese. Gomes (2007) ends by making ten recommendations to the national agenda, including the implementation of impact studies and the creation of a best-practice manual.

The following year, Saraiva (2008) picked up on this recommendation to produce the first portuguese master thesis exclusively dedicated to CPTED, which included an early approach to a best-practice manual (Saraiva and Pinho 2011). 


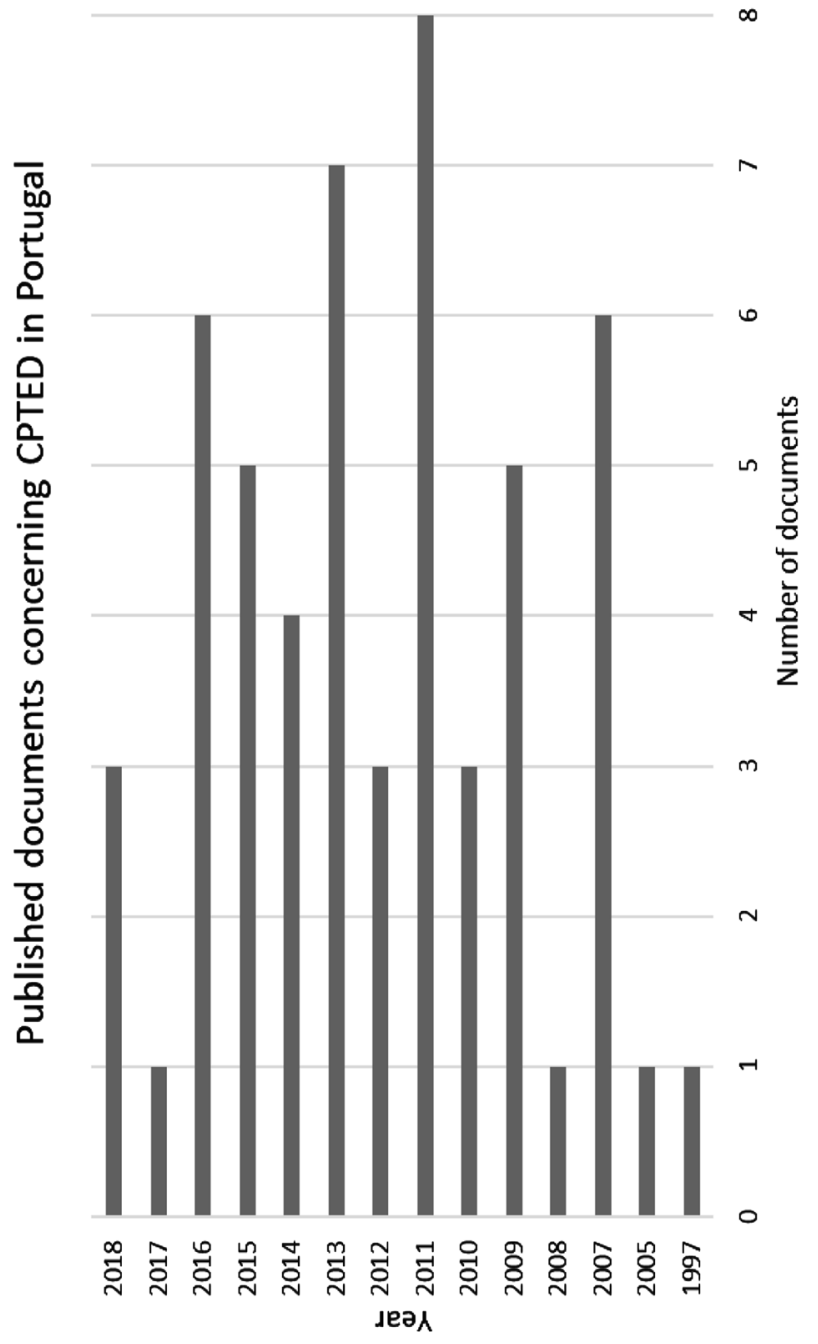

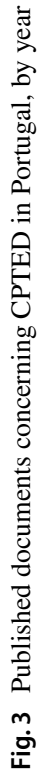

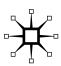




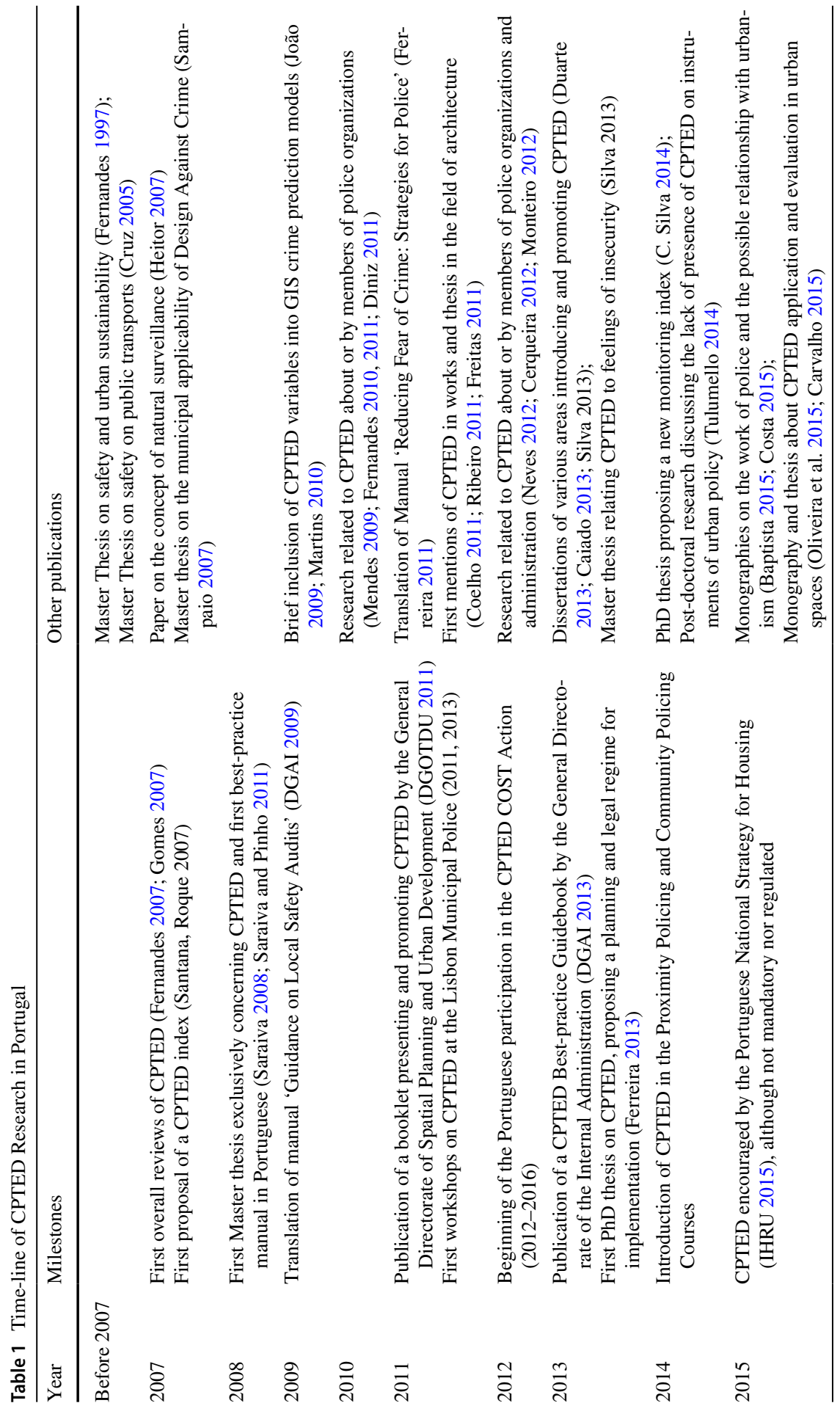




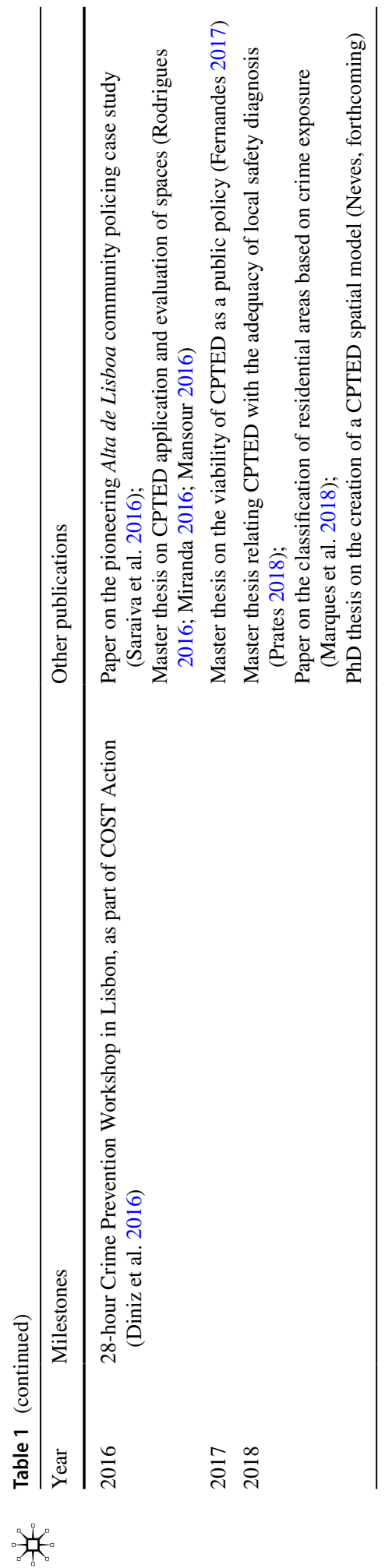




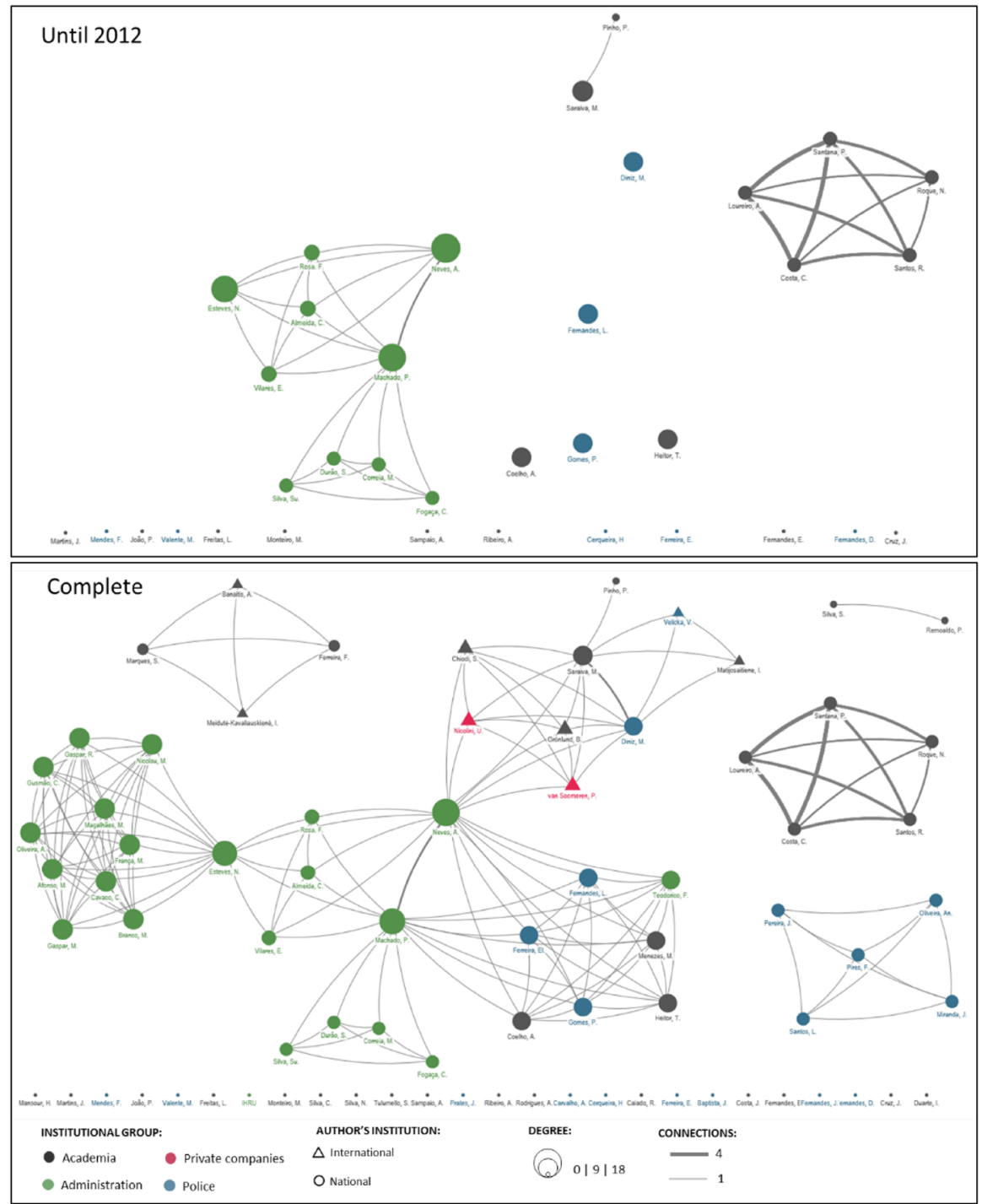

Fig. 4 Co-authorship network, until 2012 (above) and until today (below), measured by the degree of Local centrality

Concomitantly, Santana developed a CPTED score index to help quantitatively evaluate insecurity (Santana and Roque 2007; Santana et al. 2009a, b, 2010, 2014). This originated the first closed network, which today remains unconnected to the main author network (Fig. 4). This may help explain why this index has not been used since. Later on, CPTED-related variables were considered, for the first time but only marginally, in thesis about GIS-based crime prediction models (João 2009; Martins 2010). In the architectural field, Coelho (2011) and Ribeiro (2011) presented 
the principles of CPTED; whereas the master thesis of Freitas (2011) goes further, using CPTED for the first time to support intervention proposals in a problematic neighborhood.

Before, CPTED had been institutionally recognized in 2009 by the General Directorate of the Internal Administration, with the translation, coordinated by Machado, of the EFUS manual 'Guidance on Local Safety Audits' (DGAI 2009). Another manual 'Reducing Fear of Crime: Strategies for Police' was also translated (Ferreira 2011), with both promoting CPTED as a potential response to risk factors. That same year, the General Directorate of Spatial Planning and Urban Development, again under the coordination of Machado, published an original report exclusively dedicated to CPTED (DGOTDU 2011). By introducing CPTED theory and exemplifying its principles in two case studies in Lisbon, this report was the first major attempt of top-down awareness-raising by the Administration. Neves (2012), a co-author, became one of the strongest advocates of CPTED implementation in Portuguese planning and policing processes.

This dynamic was accompanied by an increasing scientific production of members of the police and military organizations. The dissertations of Mendes (2009), Fernandes (2010, 2011), Diniz (2011), Monteiro (2012) and Cerqueira (2012) address the roles and levels of CPTED-awareness of officers, decision makers, educators and legislators. These authors report little integration between police procedures and municipal planning, a gap in the legislation and academic training and a poor applicability of CPTED strategies. Diniz (2011) also notes poor awareness from the community and stakeholders, which has led her to be an active part in the integration of CPTED training in community policing, and in the CPTED workshops for stakeholders $(2011,2013,2016)$ held by the Municipal Police of Lisbon (Diniz et al. 2016; Baptista 2015). This allowed CPTED principles to be implemented in a structured way for the first time in Lisbon neighborhoods where community policing pilot projects took place. Diniz was also the police representative, along with Neves from the Administration and Saraiva from the Academia, in COST Action TU1203 - Crime Prevention Through Urban Design and Planning (2012-2016). This project was crucial to establish bridges between these three spheres of knowledge production.

\section{After 2013}

Since 2013, a further 26 documents have been produced, adding 41 authors to the network to a total of 78 authors and 191 co-authorship connections (Fig. 4). Whilst 26 authors (mostly associated to thesis) don't possess co-authorship connections, and four smaller unconnected communities exist, the main network is composed of 36 authors and is responsible for $75 \%$ of all connections. All authors therein are connected in 3-steps or less, meaning that this is a network with a high number of direct relationships, and groups of great proximity. This expansion of the core network was possible because the three spheres of knowledge production (the academia, the police and the administration) became connected, through the articulation between a small set of key authors. 
The early landmark of this period was the publication of the CPTED Best Practice Guidebook (DGAI 2013), a follow-up to the 2011 Manual. It not only allowed co-authors L. Fernandes, Heitor, Gomes and Coelho to connect to the main network (Fig. 4), it had a significant influence, albeit more on research than on practice. The number of academic works immediately increased in this period. Although some were still just introductions to the discipline (Duarte 2013), CPTED appeared associated to other themes, such as urban vegetation (Silva 2013a), and other academic works took a step further. Caiado (2013) discusses situational prevention and the articulation between officers and policies, proposing, like Gomes (2007), that security organizations should emit a "seal of approval" for urban projects. Silva (2013b; Silva and Remoaldo 2014; Silva 2013c) explains feelings of insecurity through CPTED and proposes that proximity patrolling should be more integrated with a "well-preserved urban morphology". In the first portuguese PhD thesis on CPTED, Ferreira (2013), co-author of the Guidebook, analyses CPTED characteristics of areas with large crime rates, and discusses the steps for the creation of a much needed legal planning and urban management regime. A second $\mathrm{PhD}$ thesis (Silva 2014) advances with a new CPTED index score, created by merging evaluations from existing checklists with interviews to users, thus emphasizing the importance of social action. However, like the score produced by Santana, no subsequent applications are known.

The research of Tulumello (2014) makes similar critiques, analyzing the lack of situational prevention measures in national and municipal plans. Nonetheless, the author recognizes that CPTED has gained institutional popularity. Indeed, this was the year that Public Safety Police introduced a CPTED module in its Proximity Policing course (DGT 2016), and a year later, CPTED was included in the Portuguese National Strategy for Housing (IHRU 2015), as a guiding, yet non-mandatory measure. Measure 1.1.4 states that CPTED "needs to be disseminated to the various agents of the rehabilitation processes" and that public space projects "should respect strategies of crime prevention through environmental design". The Habitat report of the following year, co-authored by Esteves (DGT 2016), also references the Lisbon CPTED initiatives.

However, as Table 1 shows, no further direct actions from the Administration were taken to disseminate CPTED or include it in Portuguese legal frameworks. Since, publications have been centered in the academia and in the police, through reports, thesis or papers. These have included, first, works which evaluate and urge for the integration of police officers and planners (Baptista 2015; Costa 2015). Both works stress that there has not been an empirical application of knowledge, and no multidisciplinary working groups have so far been created. Second, a new wave of academic works have described the application and impact of CPTED in urban spaces in Portugal, such as retail (Oliveira et al. 2015; Miranda 2016), streets and public spaces (Rodrigues 2016; Carvalho 2015), and residential areas (Mansour 2016; Marques et al. 2018). Most of these works tend to follow the guidelines present in the 2013 DGAI guidebook. More than half of the stakeholders interviewed by Rodrigues (2016) and Miranda (2016) were unaware of CPTED and Carvalho (2015) stresses that these strategies in Portugal have so far "just been an attempt". Both authors propose integrated CPTED programs. 
In 2016, signaling the end of the Crime Prevention Cost Action, the Portuguese committee published an international paper on the Portuguese CPTED and community policing experience (Saraiva et al. 2016). This paper presents the first international comparison of CPTED evolution and experiences in Portugal, by setting the pilot case of Alta de Lisboa against a Lithuanian case study. This study signals the need for more specific training on CPTED, a greater multidisciplinary articulation and openness to stakeholders, and long term monitoring of interventions. The same authors also coordinated the Lisbon Crime Prevention Workshop "Security and Urban Planning" (Diniz et al. 2016). This was a 28-h, 1-week course destined to planners, local stakeholders, municipal workers and other governmental representatives. Both studies allowed an important connection in the author network between the academia (Saraiva), the police (Diniz) and the administration (Neves), building a foundation for the integration between these spheres in research and practice.

Lastly, recent years saw the publication of more academic works, whose conclusions address similar points. Supported on a series of interviews to experts in the fields of safety and security, Fernandes (2017) discusses the viability of a CPTED program as a public policy for safety. Prates (2018) relates CPTED principles with the adequacy of local safety diagnosis, emphasizing their combined importance as basic tools of prevention. Through a survey, the author further elaborates on the lack of awareness in the organs of local administration. Finally, Neves forthcoming PhD thesis conceives a spatial model relating georeferenced crime data with socio-urbanistic variables, and again strongly advocates the use of CPTED strategies and the integration between police procedures and urbanism.

Overall, the main results of the Portuguese publications on CPTED prove that Portugal has already an established research in the various areas (academia, police and administration), which have recently started to work together. However, it is a country where the application of the principles into practice is still restricted to a few well-intentioned professionals, mainly from the Police. There is a major gap in terms of legislation and academic training. Most authors urge for a greater dissemination of principles in training spheres and institutional documents, and a greater articulation between police, the academia and planning professionals when executing projects. It is consensual that more case studies are required. Many authors also aspire to create a Portuguese CPTED network.

\section{The complete author network}

Considering the complete network (Fig. 4), the most connected authors are Neves (18 co-authorship connections) and P. Machado (16), both from the Administration. Machado is connected to authors of the academia and the police, and Neves is connected to authors in all three spheres. Esteves is also well connected, but only because he co-authored two institutional reports with a large number of co-authors (DGOTDU 2011; DGT 2016). The most connected author of the academic group is Saraiva (9 co-authorship connections), and of the police is Diniz (with 8). Both connect directly to the three spheres. 
Betweenness centrality (Fig. 5) measures in each node the amount of times a given author is passed through in order to establish shortest path connections between every two authors. In the graph it is again perceptible the Neves and P. Machado (administration), as well as Saraiva (academia) and Diniz (police), are the main connecting authors of this network. This confirms that they have been the key authors in the publication and transference of knowledge within the country, performing connections within and between distinct institutional groups that otherwise would develop research in isolation. These connections are paramount to establish future CPTED research and practice in Portugal.

\section{Analysis of cited publications}

The 54 documents cite a total of 2.740 publications, written by 2.916 authors. Only 5 documents were written before the 1900s (starting with the Statute of Winchester, 1285) and only around 12\% were written until 1990 (see Fig. 6). This means that Portuguese research on CPTED has been mostly influenced by documents of the last 30 years, with the most prolific period being from 2000 to 2003. This time-frame is coherent both with the increasing popularity of CPTED research in Europe and the research start in Portugal in the late 2000s.

The majority of cited documents are books (25\%), articles in international (nonportuguese) journals (22\%) and reports (20\%). Book chapters (9\%), conference papers $(7 \%)$ and papers in national journals (4\%) are cited to a lesser extent. Other formats such as thesis, magazine or web articles correspond to less than $3 \%$ in the citation database.

Of the 20 most cited authors, 11 are Portuguese, which denotes the importance of national authors in disseminating CPTED knowledge (see Table 2 for the Top 10). The most cited Portuguese author, second overall, is Machado (seen in the previous section as one of the most connected authors), who is cited 63 times. His most cited document is the 2011 CPTED guidebook (DGOTDU 2011). Other relevant Portuguese authors cited are Heitor (42 times), L. Fernandes and Neves (35 each), M. Valente (28), or Gomes (25). Their most cited papers are part of the list of 54 documents seen in the previous section, including many pioneering works leading up to the 2013 Manual (Heitor 2007; Valente 2007; DGOTDU 2011; Fernandes 2007; DGAI 2013). However, other Portuguese authors appear, as Lourenço (cited 40 times), and A. Esteves and J. Fernandes (25 each). All of them are from the academia, but despite different backgrounds (sociology, geography and psychology, respectively), all write expertly about feelings of insecurity. Nonetheless, none of these works acknowledges CPTED.

The most cited author overall is Ronald V. Clarke, appearing a total of 79 times. His most cited work is the book 'Situational Crime Prevention' (Clarke 1992). Other well-known CPTED authors such as Newman (cited 53 times), Cozens (51), Brantingham \& Brantingham (31), Felson (30), Saville (29) Kelling (28) or Crowe (25) appear in the top 20 of citations. Besides relying on national references, Portuguese authors are inspired by the major standards of international 


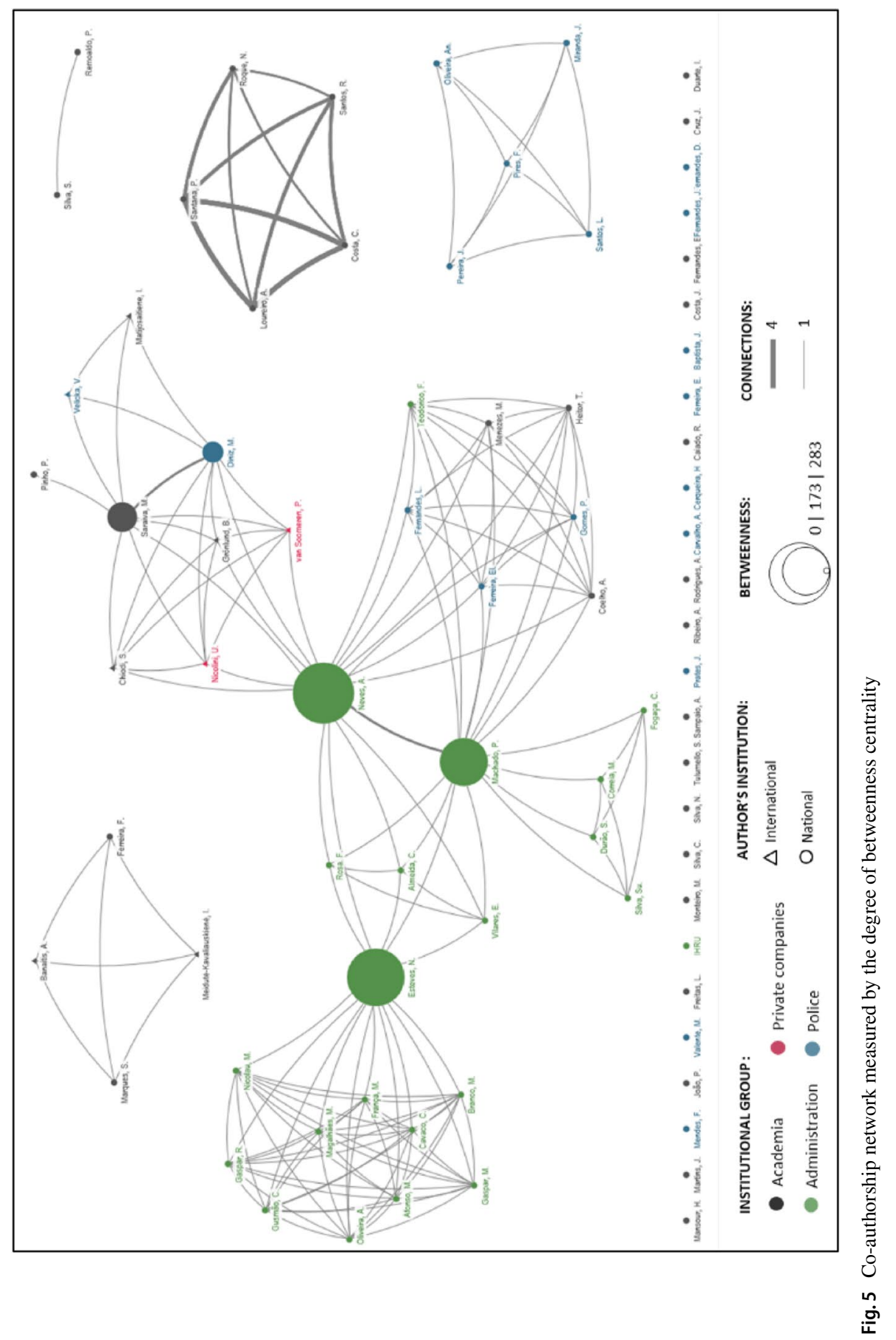

站 


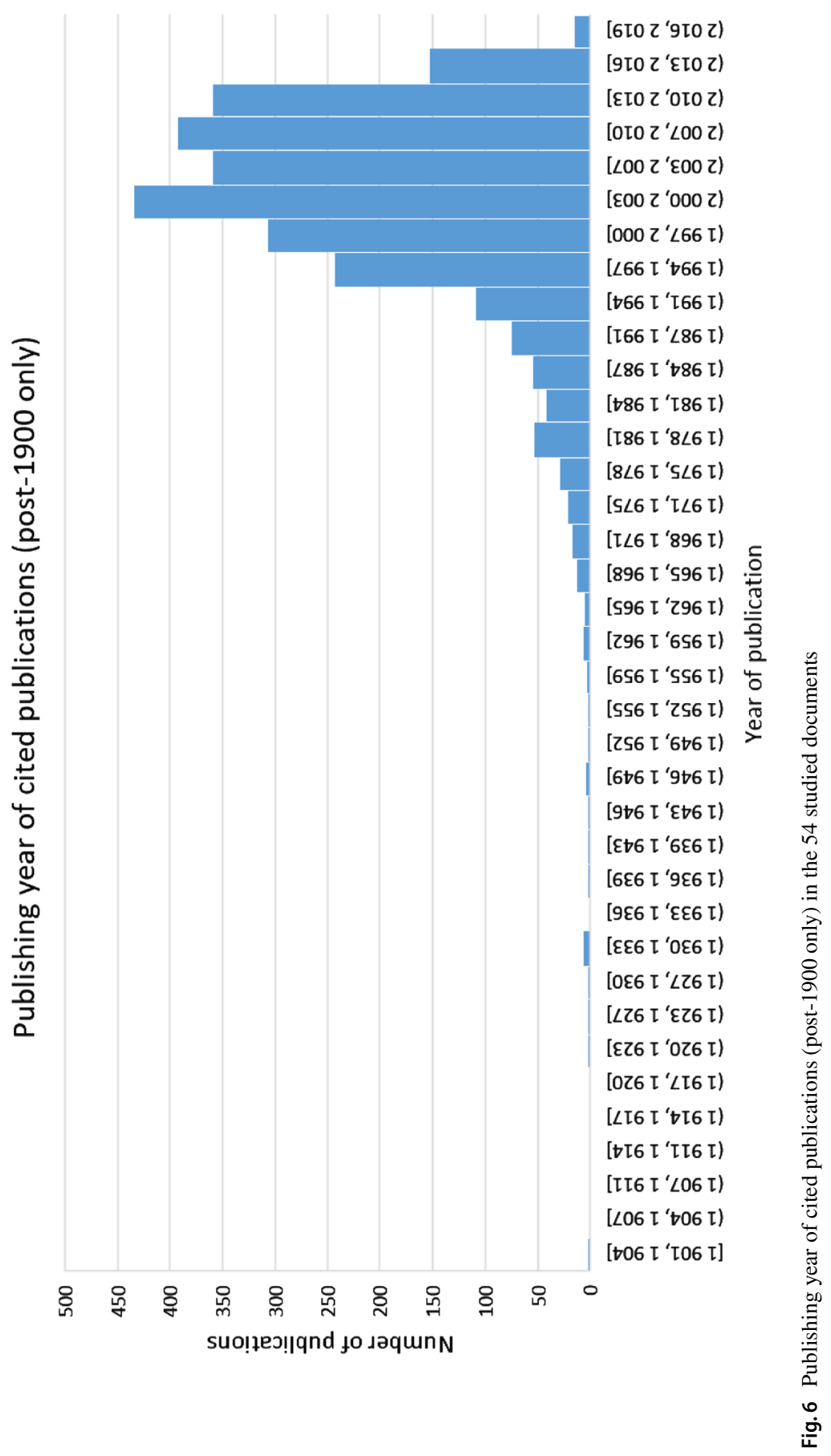


Table 2 Top 10 most cited authors within the 54 studied documents

\begin{tabular}{|c|c|c|c|c|c|}
\hline Position & Author & Nationality & $\begin{array}{l}\mathrm{N}^{\mathrm{o}} \text { of } \\
\text { times } \\
\text { cited }\end{array}$ & $\begin{array}{l}\text { Documents (of the } \\
54 \text { ) who cite the } \\
\text { author }\end{array}$ & $\begin{array}{l}\text { Documents of the } \\
\text { author which are } \\
\text { cited }\end{array}$ \\
\hline 1 & Ronald V. Clarke & British & 79 & 23 & 30 \\
\hline 2 & Paulo Machado & Portuguese & 63 & 27 & 15 \\
\hline 3 & Oscar Newman & American & 53 & 27 & 8 \\
\hline 4 & Paul Cozens & British & 51 & 22 & 20 \\
\hline 5 & Teresa Heitor & Portuguese & 42 & 23 & 4 \\
\hline 6 & Nelson Lourenço & Portuguese & 40 & 14 & 23 \\
\hline 7 & L. Fiães Fernandes & Portuguese & 35 & 19 & 6 \\
\hline 8 & Ana V. Neves & Portuguese & 35 & 20 & 3 \\
\hline 9 & P. and P.J. Brantingham & Canadians & 32 & 22 & 13 \\
\hline 10 & Marcus Felson & American & 30 & 16 & 10 \\
\hline
\end{tabular}

Despite having 34 citations, Santana's citations were all self-cited within her 4 authored documents. Hence she was not included in this Table

literature, mostly from English-speaking countries. Noteworthy is the fact that publications from Latin countries, both in Europe and South America (notably Brazil, who shares the same language) are hardly cited, despite a close cultural proximity.

Indeed, the most cited publications overall are (Table 3) Jacob's 'The death and life of great American cities' (Jacobs 1961); Newman's 'Creating defensible space' (Newman 1996); and Crowe's 'Crime prevention through environmental design' (Crowe 1991). Other international documents by leading experts as Jeffery (1971), Newman (1972), Brantingham and Brantingham (1981), Clarke (1992), Wilson and Kelling (1982) and Cozens (2002) are in the top 20. Interesting is the fact that all top 20 international publications have been published before 2002, once again emphasizing the need Portuguese researchers have, at this early stage, to support ongoing research on the classic standards of the literature.

The most cited Portuguese document is a book by Esteves on the geography of insecurity in Lisbon (Esteves 1999), one of the first works of its kind in Portugal. The previously discussed publications of Heitor (2007), Fernandes (2007) and Neves (2012), as well as Machado's report on Safer Metropolis (2007) are all in the top 20 of citations. The importance of the publications in the key year of 2007 is yet again shown. Both Portuguese CPTED manuals (DGAI 2013; DGOTDU 2011) are among the most cited, as well. 


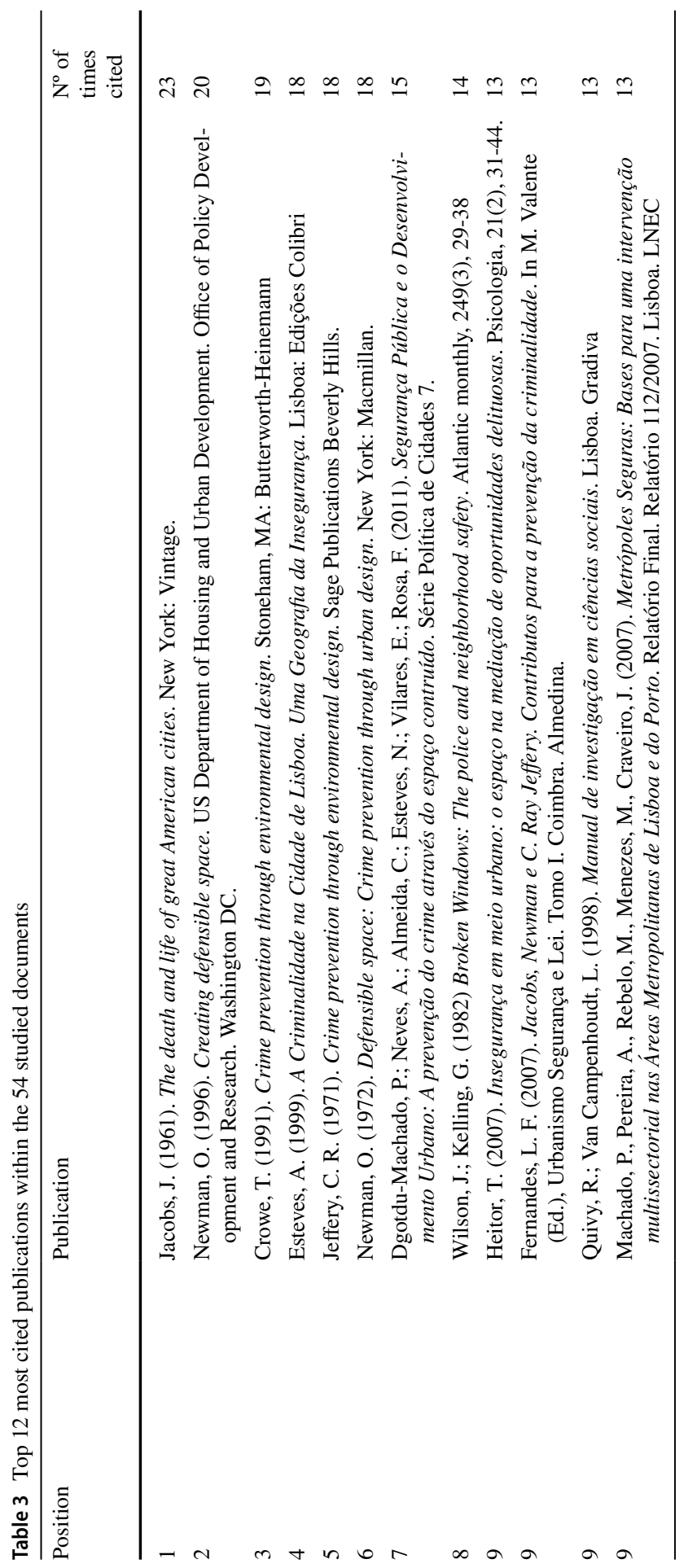




\section{Discussion and conclusions}

Taylor put it best when he named his chapter on CPTED on the Handbook of Environmental Psychology (Taylor 2003) as "CPTED: Yes, No, Maybe, Unknowable, and All of the Above". CPTED has been widely debated over the last four decades, but while its advocates have made extensive efforts to prove its effectiveness, through the documentation of numerous success stories, CPTED is still not as widely acknowledged and applied in the creation of safer places as perhaps it should be. Crowe (2000) once wrote "the greatest impediment to the widespread use of CPTED is ignorance". Even though there have always been other reasons, as many authors have debated (Schubert et al. 2016; Chiodi 2016; Saraiva et al. 2016; Armitage 2018; Gibson and Johnson 2013; Ekblom 2011b), and the relationship of space, design and crime is increasingly more complex than many CPTED studies assume (Ekblom 2011a), this one reason-lack of awarenessstill rings the truest two decades later.

CPTED has improved to cope with the times and respond to its major critiques, by evolving into a second and now a third generation. In the words of Cozens and Love (2015), CPTED has become increasingly pervasive in the twenty-first century, and is now living a new wave of popularity, also fomented by documents as the European Standard. But whist in the more advanced countries as the US, the UK or Australia the debate now focuses on how to move to a more place-based approach of CPTED, and how to incorporate urban, demographic or technological changes into CPTED practice; in other countries the acceptance of CPTED itself as a crime prevention discipline is still the issue. Countries like Portugal do not have a three- or four-decade-long history of CPTED research and practice, nor is CPTED largely known (much less accepted) in the main spheres related to public safety and place-making. However, this does not mean that there is no research and practice at all. Over the last ten years, fomented by directives from the EU and a multitude of safety concerns derived from a range of social and economic phenomena, countries of southern and eastern Europe have awakened to CPTED principles and have started their slow catch-up processes.

In this paper, we have presented the Portuguese time-line to the international community, an over decade-long process that has resulted in a series of awareness-raising initiatives and over 50 published works ranging from academic thesis to government-promoted guidebooks. Using for the first time SNA and bibliometric research techniques to analyze documents, authors, institutions and cited sources (let's call them the major sources of inspiration for Portuguese researchers), three points are made very clear.

The first point is the importance of the administrative leadership for disseminating CPTED and consolidating CPTED knowledge. As Saraiva et al. (2019) note, before the CPTED Guidebook of the General Directorate of the Internal Administration (DGAI 2013) there were at least thirteen different translations of the term CPTED into Portuguese. After this guidebook, practically all subsequent documents use the translation the Guidebook introduced (roughly "Crime Prevention Through Constructed Space"). Furthermore, in the present paper it has been 
seen that this Guidebook has been directly cited by around $40 \%$ of the Portuguese documents since.

The second point is the importance of integration, and projects that promote integration, to disseminate knowledge between spheres of production and learning. Previous academic research was very important to raise awareness and inspire the administration to produce its two major reports, for which experts from different backgrounds and institutions were invited. Without these two documents and without the partnership established between the academia, the administration and the police within the COST research project, the author network would be very different indeed. The spheres of knowledge would not be extensively connected, nor would have such a small average number of shortest path connecting steps between all members of the main network, hence further hindering implementation.

The third point is that, as a discipline still in its infancy in Portugal, CPTED research is mainly inspired on a small set of national authors (it is a self-citing knowledge network) and on the major standards of international literature, mostly prior to the year 2000. Arguably, researchers and authors in Portugal still feel the need to consolidate the theoretical basis of CPTED (dwelling on authors as Jacobs, Newman or Crowe), before moving to more empirical, hands-on and up-to-date research. Hardly any document discusses the most recent debates and trends on the international CPTED scene, focusing instead on the principles of the discipline and pilot Portuguese experiences. The presence of Portugal and Portuguese researchers in major forums as ICA or EDOCA is virtually inexistent, and CPTED is still just a recommendation (almost a novelty that keeps being introduced) in a few planning and safety documents.

Nonetheless, we argue that the slow consolidation of the author network and the integration between the various spheres of learning is paramount for the implementation of CPTED into legislation and practice. Hence, an approach as that adopted in this paper is important to the future of CPTED research and practice in countries where the basis of research are still being developed, as it constitutes an evaluation tool of organizational self-awareness. It is a means to display, acknowledge, and scientifically validate a research field that for the largest part of its recent existence occurred as separate, unconnected poles. This awareness can greatly add to acceptance and further cement integration between the various areas of expertise in the academia, the police, the administration and also the private sector. By using a consolidated research methodology of social sciences within CPTED-related research, we don't only increase the span of this research at a global scale, but we are also able to determine who the players are and what has been their approach to the problem. More importantly, we can understand how to more easily integrate and disseminate knowledge.

Although CPTED is far from a new concept, it is still something fresh to many authorities and communities in countries such as Portugal. Hence, there is room to learn from successful international experiences but also to provide innovative test-cases at local level, as often there has not been a strong top-down approach to CPTED. We thus believe this to be a highly replicated methodology, both for organizing research paths in more up-to-date countries, and assisting other countries still building their CPTED culture and facing similar constraints of research, 


\section{awareness-raising and implementation within urban planning and rehabilitation agendas.}

Acknowledgements This work, as part of project CANVAS-Towards Safer and Attractive Cities: Crime and Violence Prevention through Smart Planning and Artistic Resistance, was supported by the European Regional Development Funds through the COMPETE 2020-Operational Programme 'Competitiveness and Internationalization' under Grant POCI-01-0145-FEDER-030748. In addition, as part of the Centre of Studies on Geography and Spatial Planning (CEGOT) of the University of Porto, this work was partially supported by National Funds through the Portuguese Foundation for Science and Technology (FCT) under Grant UID/GEO/04084/2019. We would also like to thank Ana Verónica Neves, Mónica Diniz and Laura Jota for their contributions to the early stages of this research. Finally, we wish to thank the two anonymous Referees for their invaluable contribution to the final form of this paper.

Open Access This article is licensed under a Creative Commons Attribution 4.0 International License, which permits use, sharing, adaptation, distribution and reproduction in any medium or format, as long as you give appropriate credit to the original author(s) and the source, provide a link to the Creative Commons licence, and indicate if changes were made. The images or other third party material in this article are included in the article's Creative Commons licence, unless indicated otherwise in a credit line to the material. If material is not included in the article's Creative Commons licence and your intended use is not permitted by statutory regulation or exceeds the permitted use, you will need to obtain permission directly from the copyright holder. To view a copy of this licence, visit http://creativecommons.org/licen ses/by/4.0\%.

\section{References}

APAV. 2017. Statistics. www.apav.pt.

Armitage, R. 2016. Crime prevention through environmental design. In: Environmental Criminology and Crime Analysis. Abingdon, UK: Routledge

Armitage, R. 2018. Burglars' take on crime prevention through environmental design (CPTED): Reconsidering the relevance from an offender perspective. Security Journal 31: 285-304.

Baldwin, J., O.M.K. Alhawi, S. Shaughnessy, A. Akinbi, and A. Dehghantanha. 2018. Emerging from the Cloud: A Bibliometric Analysis of Cloud Forensics Studies. In Cyber Threat Intelligence, ed. A. Dehghantanha, M. Conti, and T. Dargahi. Cham: Springer.

Baptista, J. 2015. A Segurança no Desenho Urbano: Uma Abordagem CPTED. Academia Militar: Relatório Científico Final do Trabalho de Investigação Aplicada.

Bichler, G., and A. Malm. 2008. A social network analysis of the evolution of the environmental criminology and crime analysis (ECCA) symposiums. Crime Patterns and Analysis 1: 5-22.

Borgatti, S., M. Everett, and J. Johnson. 2013. Analyzing Social Networks. London: Sage.

Bosco, A., and S. Verney. 2012. Electoral Epidemic: The Political Cost of Economic Crisis in Southern Europe, 2010-11. South European Society and Politics 17: 129-154.

Brantingham, P.J., and P.L. Brantingham. 1981. Environmental Criminology. Beverly Hills, CA: Sage.

Caiado, R. 2013. O sentimento de insegurança e a sua interação com a criminalidade. Mestrado em Ciências Juridico-Políticas, Universidade Autónoma de Lisboa.

Cardia, C. 2013. The European Standard for Crime Prevention Through Environmental Design. Built Environment 39: 49-73.

Carneiro, A., P. Portugal, and J. Varejão. 2014. Catastrophic job Destruction during the Portuguese Economic Crisis. Journal of Macroeconomics 39: 444-457.

Carvalho, A. 2015. A Segurança Urbana e o Desenho do Espaço Público: Contributos Para a Prevenção do Crime e de Incivilidades. Lisbon: Mestrado em Ciências Policiais, Instituto Superior de Ciências Policiais e Segurança Interna.

Cerqueira, H. 2012. A "Criminalidade de Rua" na Freguesia de Campelo: Estudo de Caso. Lisbon: Relatório Científico Final do Trabalho de Investigação Aplicada, Academia Militar. 
CEU. 2011. Council conclusions on encouraging Crime Prevention Through Environmental Design (CPTED) 3081st JUSTICE and HOME AFFAIRS Council meeting Council of the European Union (Justice and Home Affairs).

Chiodi, S.I. 2016. Crime prevention through urban design and planning in the smart city era: The challenge of disseminating CP-UDP in Italy: learning from Europe. Journal of Place Management and Development 9: 137-152.

Clarke, R. 1992. Situational Crime Prevention: Successful Case Studies. New York: Harrow \& Heston.

Coelho, A. 2011. Segurança Arquitectónica Residencial e Urbana. Ano VII: Infohabitar.

Costa, J. 2015. Relações Segurança Pública e Desenvolvimento Urbano. Cedis Working Papers, 14.

Cozens, P.M. 2002. Sustainable urban development and crime prevention through environmental design for the British city. Towards an effective urban environmentalism for the 21 st century. Cities 19: 129-137.

Cozens, P.M., and T. Love. 2015. A review and current status of crime prevention through environmental design (CPTED). Journal of Planning Literature 30: 393-412.

Cozens, P. M. \& Melenhorst, P. Exploring community perceptions of crime and crime prevention through environmental design (CPTED) in Botswana. The British Criminology Conference, 2014 Edge Hill University, Lancashire. 65-83.

Cozens, P.M., G. Saville, and D. Hillier. 2005. Crime prevention through environmental design (CPTED): a review and modern bibliography. Property Management 23: 328-356.

Crowe, T. 1991. Crime Prevention Through Environmental Design. Stoneham, MA: Butterworth-Heinemann.

Crowe, T. 2000. Crime Prevention Through Environmental Design: Applications of Architectural Design and Space Management Concepts, 2nd ed. Oxford: Butterworth-Heinemann.

Cruz, J. 2005. Design contra o crime nos transportes públicos de Lisboa e Porto. Mestrado em Design, Materiais e Gestão do Produto, Universidade de Aveiro.

Davey, C., and A. Wootton. 2017. Design Against Crime: A Human-Centred Approach to Designing for Safety and Security. New York: Routledge.

DGAI. 2009. Manual de diagnósticos locais de segurança: Uma compilação de normas e práticas internacionais. http://efus.eu/files/fileadmin/efus/Publications/Manual_Seguranca_miolo_166pp _23_12_09.pdf: Direcção Geral de Administração Interna.

DGAI. 2013. CPTED-Prevenção Criminal através do Espaço Construído-Guia de Boas Práticas. Lisboa: Direcção Geral das Actividades Económicas.

DGOTDU. 2011. Segurança Pública e o Desenvolvimento Urbano: A prevenção do crime através do espaço contruído. Política de Cidades. http://www.dgterritorio.pt/produtos_e_servicos/publicacoe s/serie_politica_de_cidades/7_seguranca_publica_e_desenvolvimento_urbano_a_prevencao_ do_crime_atraves_do_espaco_construido/: DGOTDU - Direcção Geral do Território.

DGT. 2016. Habitat III - Relatório Nacional Portugal. In: CAVACO, C. (ed.). http://habitatiii.dgter ritorio.pt/sites/default/files/ficheiros_publicos/PT_UN-HabitatIII_NationalReport_2016_08_04_ PT.pdf: Direcção Geral do Território.

Diniz, M. 2011. Práticas policiais e cidadania a nível local: a participação dos cidadãos no contexto do policiamento comunitário "Alvalade mais seguro". Mestrado em Sociologia e Planeamento, ISCTE - Instituto Universitário de Lisboa.

Diniz, M., Saraiva, M., Neves, A. V., Van Soomeren, P., Nicolini, U., Chiodi, S. I. \& Grönlund, B. 2016. Lisbon CP-UDP Workshop-Security and Urban Planning. In: COST ACTION TU1203 (ed.) Working Group Report. http://www.costtu1203.eu/wp-content/uploads/2017/12/LisbonCOST Workshop_FinalReport.pdf.

Duarte, I. 2013. Planeamento, Segurança e Exclusão Social na Ótica da Prevenção Criminal. Licenciatura em Criminologia, Universidade Fernando Pessoa.

Durão, S. 2011. Polícia, segurança e crime em Portugal: ambiguidades e paixões recentes. Etnográfica 15: 129-152.

Ekblom, P. 2011a. Crime Prevention, Security and Community Safety Using the 5Is Framework. Basingstoke: Palgrave Macmillan.

Ekblom, P. 2011b. Deconstructing CPTED... and reconstructing it for practice, knowledge management and research. European Journal on Criminal Policy and Research 17: 7-28.

Ekblom, P., R. Armitage, L. Monchuk, and B. Castell. 2013. Crime prevention through environmental design in the United Arab Emirates: a suitable case for reorientation? Built Environment 39: $92-113$. 
Esteves, A. 1999. A Criminalidade na Cidade de Lisboa. Uma Geografia da Insegurança. Lisbon: Edições Colibri.

EUCPN. 2002. European Crime Prevention Network First Annual Report: 2001. In: Council of the European Union (Justice and Home Affairs and Civil Protection) (ed.). http://www.europarl.europa.eu/ RegData/docs_autres_institutions/conseil/2002/08327/CONS_CONS(2002)08327_EN.doc.

Eurostat. 2016. Crime and criminal justice statistics. Statistics Explained. http://ec.europa.eu/eurostat/ statistics-explained/index.php/Main_Page.

Fernandes, D. 2010. Urbanismo e Segurança Contributos da Concepção, Manutenção e Utilização do Espaço para a Prevenção Criminal. Uma abordagem ao bairro da Bela Vista, em Setúbal. Mestrado em Ciências Policiais, Instituto Superior de Ciências Policiais e Segurança Interna.

Fernandes, D. 2011. CONSTRUIR SEGURANÇA: Prevenção do crime através da concepção do espaço. Infohabitar, VII.

Fernandes, E. 1997. Segurança e sustentabilidade: Processos urbanos e criminalidade na cidade do Porto do século XX. Mestrado em Planeamento e Projeto do Ambiente Urbano, Faculdades de Arquitectura e Engenharia da Universidade do Porto

Fernandes, J. 2017. Segurança No Planeamento Urbanístico: A Criação de um Programa CPTED. Academia Militar: Mestrado Integrado em Ciências Militares na especialidade de Segurança.

Fernandes, L. F. 2007. Jacobs, Newman e C. Ray Jeffery. Contributos para a prevenção da criminalidade. In: Valente, M. (ed.) Urbanismo Segurança e Lei. Tomo I. Coimbra: Almedina.

Ferreira, E. 2011. Reduzir o Medo do Crime (Como Combater o Sentimento de Insegurança Pública): Estratégias Policiais. Secção de Prevenção Pública e Proximidade (SPPP), do Comando Distrital de Polícia de Aveiro (CDPAVR): Tradução do Manual "Reducing Fear of Crime: Strategies for Police" de Gary Cordner; Kutztown University (2010).

Ferreira, E. 2013. Segurança e Prevenção da Criminalidade em Espaços Públicos: A dialética proativa entre o desenho e o uso seguro. Doutororamento em Urbanismo, Faculdade de Arquitetura da Universidade Técnica de Lisboa.

Freitas, L. 2011. Influência do desenho urbano na insegurança da cidade - Uma proposta para o bairro da Cova da Moura. Mestrado em Arquitectura, Instituto Superior Técnico - Universidade Técnica de Lisboa.

Gibson, V., and D. Johnson. 2013. CPTED, but not as we know it: investigating the conflict of frameworks and terminology in crime prevention through environmental design. Security Journal 29 (2): $256-275$.

Gomes, P.V. 2007. A Prevenção Criminal através do Ordenamento do Espaço Urbano: Subsídios para uma Agenda Nacional. In Urbanismo Segurança e Lei. Tomo I, ed. M. Valente. Almedina: Coimbra.

Grangeia, H., O. Cruz, R. Teixeira, and P. Alves. 2013. Vulnerabilidades urbanas: O caso da criminalidade associada às ourivesarias na cidade do Porto. Revista Latitudes 7: 69-89.

Grönlund, B. 2014. A European bibliographic overview across the language barriers - including some questions on terminology. In: COST ACTION TU1203: WORKING GROUP 1 (ed.) Cost Action Booklet. http://www.costtu1203.eu/.

Grönlund, B., Altes, H., Soomeren, P. V. \& Stummvoll, G. 2014. Review of CEN 14383. The death and life of great European standards and manuals-Development and implementation of the CEN 14383 standards. In: COST ACTION TU1203: WORKING GROUP 2 (ed.) Cost Action Booklet. http://www.costtu1203.eu/.

Haider, M.A., and P. Iamtrakul. 2018. Theoretical concepts of crime and practices in urban planning and design process for safe urban life. International Journal of Building, Urban, Interior and Landscape Technology; BUILT 12: 7-24.

Heitor, T.V. 2007. Insegurança em meio urbano: o espaço na mediação de oportunidades delituosas. Psicologia 21: 31-44.

Hino, K., and R.H. Schneider. 2013. Planning for crime prevention in Japan. Built Environment 39: 114-139.

Hollis-Peel, M., D. Reynald, M. van Bavel, H. Elffers, and B. Welsh. 2011. Guardianship for crime prevention: a critical review of the literature. Crime, Law and Social Change 56: 53-70.

IEP. 2019. Global Peace Index 2019: Measuring Peace in a Complex World. http://visionofhumanity.org/ reports: Institute for Economics \& Peace.

IHRU. 2015. Estratégia Nacional para a Habitação - Desafios e Mudanças. aprovada através da Resolução de Conselho de Ministros n..$^{\circ}$ 48/2015, 15 de julho, disponível em: https://www.portaldahabitac 
ao.pt/opencms/export/sites/portal/pt/portal/habitacao/EstNacHabitacao/ENpH_PT_FINAL.pdf: Ministério do Ambiente, Ordenamento do Território e Energia.

INE. 2019. Statistics Portugal. www.ine.pt/[Online]. Accessed 2019.

Jacobs, J. 1961. The Death and Life of Great American Cities. New York: Vintage.

Jeffery, C.R. 1971. Crime Prevention Through Environmental Design. Beverly Hills, CA: Sage.

João, P. 2009. Modelo Preditivo de Criminalidade: Georeferenciação ao Concelho de Lisboa. Mestrado em Estatística e Gestão de Informação, Inbstituto Superior de Estatística e Gestão de Informação, Universidade Nova de Lisboa.

Johnson, D., V. Gibson, and M. McCabe. 2014. Designing in crime prevention, designing out ambiguity: Practice issues with the CPTED knowledge framework available to professionals in the field and its potentially ambiguous nature. Crime Prevention Community Safety 16: 147-168.

Jongejan, A., and T. Woldendorp. 2013. A successful CPTED approach: The Dutch'Police label secure housing'. Built Environment 39: 31-48.

Machado, H. \& Santos, F. 2009. A moral da justiça e a moral dos media: julgamentos mediáticos e dramas públicos. Caminhos nas Ciências Sociais, 49.

Machado, P., Pereira, Á., Rebelo, M., Menezes, M. \& Lutas Craveiro, J. 2007. Metrópoles Seguras: Bases para uma intervenção multissectorial nas Áreas Metropolitanas de Lisboa e do Porto. LNEC 114/2007.

MAI./ 2016. Contratos Locais de Segurança-Nova Geração. http://www.portugal.gov.pt/media /20490378/20160714-mai-contratos-locais-seguranca.pdf: Gabinete da Secreatria de Estado Adjunta e da Administração Interna.

Mansour, H. 2016. Liveable Urban Areas and New Housing Typologies: A Case Study In Vila Nova de Famalicão, Portugal. Mestrado em Planeamento e Projecto Urbano, Faculdade de Engenharia da Universidade do Porto.

Marques, S.C.R., F.A.F. Ferreira, I. Meidutè-Kavaliauskienė, and A. Banaitis. 2018. Classifying urban residential areas based on their exposure to crime: A constructivist approach. Sustainable Cities and Society 39: 418-429.

Martins, J. 2010. Os sistemas de informação geográfica na gestão da criminalidade em Portugal. Mestrado em Gestão do Território (Area de especialização em Detecção remota e Sistema de Informação de Geográfica), Universidade Nova de Lisboa, Faculdade de Ciências Sociais e Humanas.

Mendes, F. 2009. Urbanismo e suas implicações na segurança. Curso de Infantaria, Academia Militar Guarda Nacional Republicana.

Michael, S. E., Saville, G. \& Warren, J. W. 2012. A CPTED bibliography: Publications related to urban space, planning, architecture, and crime prevention through environmental design, 19752010. Landscape Architecture and Environmental Planning Faculty Publications, 65.

Miranda, J. 2016. Comércio Tradicional: Contributos Para a Prevenção Situacional de Comportamentos Antissociais. Lisboa: Mestrado em Ciências Policiais, Instituto Superior de Ciências Policiais e Segurança Interna.

Monchuk, L. 2019. A Decade Developing the Delivery of CPTED Across Greater Manchester. In Rebuilding Crime Prevention Through Environmental Design: Strengthening the Links with Crime Science, ed. R. Armitage and P. Ekblom, 199-215. London: Routledge.

Monchuk, L., and G. Clancey. 2013. A comparative analysis of crime risk assessments and their application in Greater Manchester and New South Wales. Built Environment 39: 74-91.

Monteiro, M. 2012. O papel das polícias municipais na prevenção do crime: contributos e perceções da polícia municipal de Lisboa. Mestrado em Administração Pública (especialização em Administração da Justiça), Instituto Superior de Ciências Sociais e Políticas, Universidade Técnica de Lisboa.

Neves, A. V. 2012. A Criminalidade de Rua e o Contexto. VII Congresso Português de Sociologia. Faculdade de Psicologia e Ciências da Educação, Porto.

Newman, O. 1972. Defensible Space: Crime Prevention Through Urban Design. New York: Macmillan.

Newman, O. 1996. Creating Defensible Space. Washington, DC: US Department of Housing and Urban Development, Office of Policy Development and Research.

Oliveira, A., Pires, F., Miranda, J., Pereira, J. \& Santos, L. 2015. O Comércio Tradicional: Prevenção da Criminalidade Através do Design Ambiental. Working paper, ISCPSI.

Oxley, J. 2005. Crime Opportunity Profiling of Streets (COPS), A Quick Crime Analysis, Rapid Implementation Approach. Watford: Building Research Establishment (BRE). 
Pordata. 2019. Base de dados Portugal Contemporâneo. http://www.pordata.pt. [Accessed March 2019].

Prates, J. 2018. Prevenção Criminal em Meio Urbano: Orientações normativas e instrumentos de diagnóstico e intervenção à escala local. Relatório Científico Final de Trabalho de Investigação Aplicada. Mestrado Integrado em Ciências Militares, na especialidade Segurança, Academia Militar

Ribeiro, A. 2011. Arquitectura e Urbanismo como Factores de Segurança Pública. Mestrado em Arquitectura, Universidade Lusófona de Humanidades e Tecnologias, Departamento de Arquitectura

Rodrigues, A. 2016. A Gestão do Espaço Construído e a Prevenção Criminal: O caso da Avenida Luísa Todi em Setúbal. Mestrado em Direito e Segurança: Faculdade de Direito, Universidade Nova de Lisboa.

Sampaio, Á. 2007. Design Against Crime: Prevenção Situacional do Crime em Espaço Urbano. Mestrado em Design: Materiais e Gestão do Produto, Universidade de Aveiro.

Santana, P., Costa, C. \& Loureiro, A. 2014. Os Sistemas de Informação Geográfica e o Planeamento Urbano Saudável na Amadora. Revista do Departamento de Geografia, 368-389.

Santana, P. \& Roque, N. 2007. A (In) Segurança na Amadora. In: Santana, P. (ed.) A Cidade a a Saúde. Coimbra: Edições Almedina.

Santana, P., Santos, R., Costa, C. \& Loureiro, A. 2009a. Criar Cidade: Amadora Saudável e Activa. Relatório Final. https://www.researchgate.net/publication/270507622_Criar_Cidade_Amado ra_Saudavel_e_Ativa: Universidade de Coimbra.

Santana, P., Santos, R., Costa, C., Roque, A. \& Loureiro, A. 2010. Crime: impacts of urban design and environment. TRIA - Rivista internazionale di cultura urbanistica, 5.

Santana, P., Santos, R., Costa, C., Roque, N. \& Loureiro, A. Crime and urban environment: Impact on human health. City Futures in a Globalising World. An international conference on globalism and urban change, $2009 \mathrm{~b}$.

Saraiva, M. 2008. Planeamento e Concepção dos Espaços Públicos na Óptica da Prevenção da Criminalidade. Porto: Mestrado em Engenharia Civil - Planeamento, Faculty of Engineering of the University of Porto.

Saraiva, M., and P. Pinho. 2011. A comprehensive and accessible approach to crime prevention in the planning and design of public spaces. Urban Design International 16: 213-226.

Saraiva, M., I. Matijosaitiene, M. Diniz, and V. Velicka. 2016. Model (my) neighbourhood-a bottomup collective approach for crime-prevention in Portugal and Lithuania. Journal of Place Management and Development 9: 166-190.

Saraiva, M., A.V. Neves, H. Santos, M. Diniz, L. Jota, and P. Ribeiro. 2019. A Prevenção Criminal através do Espaço Construído (CPTED) em Portugal: revisão da literatura e redes de conhecimento. Revista Portuguesa de Estudos Regionais 52: 7-24.

Schubert, H., Soomeren, P. V., Saraiva, M., Diniz, M., Idrovo, D., LE Calloch, M., Rybka, A., Samatas, M. \& Stanarevic, S. 2016. Cooperation in Partnerships and Process of CPUDP-Results of Working Group 1. In: Cost ACTION TU1203: WORKING GROUP 1 (ed.) Cost Action Booklet. http://www.costtu1203.eu/.

Shamsuddin, S.B., and N.A. Hussin. 2013. Safe city concept and crime prevention through environmental design (CPTED) for urban sustainability in Malaysian cities. American Transactions on Engineering \& Applied Sciences 2: 223-245.

Silva, N. 2013a. Estudo da Relação Entre O Crime E A Flora Urbana Numa Metrópole Portuguesa. Faculdade de Ciências Humanas e Sociais da Universidade Fernando Pessoa.

Silva, S. 2013b. A Criminalidade e a Insegurança-Influência da Malha Urbana. GeoPlanUM II: 3-9.

Silva, S. 2013c. Geografia da (In)Segurança no Município de Guimarães. Geografia: Mestrado em Planeamento e Gestão do Território, Universidade do Minho.

Silva, C. 2014. Segurança Urbana-A Arquitetura ao Serviço da Diversidade: OIhares paralelos entre Portugal e o Brasil. Doutoramento em Arquitetura. Especialidade Teoria e Prática do Projeto, Faculdade de Arquitectura da Universidade de Lisboa.

Silva, S. and Remoaldo, P. A Geografia da (in)segurança num município português de média dimensão. The overarching issues of the european space:the territorial diversity of opportunities in a scenario of crisis, 2014 Faculdade de Letras da Universidade do Porto. 157-178.

Soomeren, P. V. Safe and secure cities. 'Conference on the reduction of urban insecurity' (general introduction), 1987 Barcelona (Spain). 
Soomeren, P. V. 2014. Roots of CP-UDP and general principles of CPTED. Draft for the Estonian CPTED manual/training.

Spinak, E. 1996. Diccionario Enciclopédico de Bibliometría. Caracas: UNESCO.

SSI 2019. Relatório de Segurança Interna 2018. www.portugal.gov.pt: Sistema de Segurança Interna.

Stummvoll, G. 2012. Governance through norms and standards: the normative force behind designled crime prevention. Criminology and Criminal Justice 12: 377-396.

Sweileh, W.M. 2018. Research trends on human trafficking: a bibliometric analysis using Scopus database. Globalization and Health 14: 106.

Taylor, R. 2003. Crime Prevention through Environmental Design (CPTED): Yes, No, Maybe, Unknowable, and All of the Above. In Handbook of Environmental Psychology, ed. R.B. Bechtel and A. Churchman. New York: Wiley.

Torres, F. 2009. Back to external pressure: Policy responses to the financial crisis in Portugal. South European Society and Politics 14: 55-70.

Tulumello, S. 2014. Local Policies for Urban Security and Spatial Planning in the Lisbon Metripolitan Area: The cases of Lisbon, Cascais and Barreiro Municipalities. ICS - Estudos e Relatórios. http://repositorio.ul.pt/handle/10451/15721: Institute of Social Sciences, University of Lisbon.

Tulumello, S. 2018. Segurança urbana: Tendências globais, contradições portuguesas e tempos de crise. A cidade em reconstrução. Leituras círitcas 2008-2018: 73-80.

Valente, M. 2007. Urbanismo, Segurança e Lei - Tomo I, Coimbra, Almedina

Vieno, A., M. Roccato, and S. Russo. 2013. Is fear of crime mainly social and economic insecurity in disguise? A multilevel multinational analysis. Journal of Community \& Applied Social Psychology 23: 519-535.

Wilson, J.Q., and G.L. Kelling. 1982. Broken windows. Atlantic monthly 249: 29-38.

Publisher's Note Springer Nature remains neutral with regard to jurisdictional claims in published maps and institutional affiliations. 